\title{
Implementasi CEDAW tentang Penghapusan Diskriminasi Perempuan: Studi Kasus Pemilu di Indonesia Tahun 2009 dan 2014
}

\author{
Angelia Maria Valentina dan Elisabeth A. Satya Dewi \\ Prodi Hubungan Internasional, Universitas Katolik Parahyangan \\ Email : angelia.mvalentina@gmail.com dan elisabeth.dewi@unpar.ac.id
}

\begin{abstract}
Abstrak
Perserikatan Bangsa-Bangsa (PBB) sebagai organisasi internasional mengeluarkan sebuah konvensi internasional yang menjadi instrumen untuk menghapus segala bentuk diskriminasi terhadap perempuan, yang dinamakan Konvensi Internasional CEDAW (Convention on Elimination of All Form of Discrimination Against Women). Sebagai salah satu negara yang meratifikasi konvensi tersebut, Indonesia, mengadopsi pasal yang ada di dalam Konvensi CEDAW menjadi UU RI No. 7 Tahun 1984. Indonesia sepakat untuk mencegah segala tindakan diskriminasi terhadap perempuan dan menjalankan seluruh kebijakan yang telah diatur didalam UU tersebut. Namun melihat realita di lapangan, jumlah partisipasi politik perempuan di Indonesia belum mendekati angka 30\% sesuai dengan affirmative action yang berlaku di Indonesia. Pemilu 2009 dan 2014 menunjukkan jumlah keterwakilan perempuan di parlemen yang masih rendah. Keberhasilan dari pelaksanaan Konvensi CEDAW yang dilihat dari jumlah partisipasi politik perempuan Indonesia diukur menggunakan sebuah indikator internasional yang dinamakan GEM (Gender Empowerment Measure). Hasil dari tulisan ini membuktikan implementasi Konvensi CEDAW di bidang partisipasi politik dinilai belum efektif karena jumlah perempuan di parlemen belum seimbang dengan jumlah penduduk perempuan.
\end{abstract}

Kata kunci : affirmative action, gem, konvensi cedaw, partisipasi politik perempuan.

\begin{abstract}
United Nations as international organization issued an international convention to eliminate discrimination towards women, called CEDAW (Convention on Elimination of All Form of Discrimination Against Women). As the one of the nation that ratified the convention, Indonesia, adopted CEDAW articles that becomes UU RI No. 7 Tahun 1984. Indonesia agreed to prevent further discrimination towards women and implement all the policies written on those article. Unfortunately, the success and implementation of CEDAW is still doubtful, especially in political realm. The number of women political participation never reached $30 \%$ according to the affirmative action that is stated in Indonesian Constitution. The 2009 and 2014 general election showed that women's representation in parliament in still low and not having significant change. The success of CEDAW can be seen from women's political participation, measured by international indicator called GEM (Gender Empowerment Measure). GEM is used to measure shift and effectiveness of the implementation of CEDAW Convention in Indonesia, especially in political participation. This article concluded that CEDAW International Convention in political participation is not effective yet, considering the number of women in parliament not balanced with ratio of women citizen in Indonesia.
\end{abstract}

Keywords: affirmative action, gem, cedaw convention, women's political participation. 
2 Angelia Maria Valentina dan Elisabeth A. Satya Dewi Implementasi CEDAW tentang Penghapusan Diskriminasi Perempuan: Studi Kasus Pemilu di Indonesia Tahun 2009 dan 2014

\section{Pendahuluan}

Di era globalisasi seperti sekarang, banyak isu-isu yang menarik perhatian masyarakat dunia. Salah satunya adalah isu hubungan internasional mengenai kesetaraan gender. Permasalahan ini tentu menjadi tantangan bagi negara sebagai aktor dalam hubungan internasional. Jika dahulu perempuan hanya mengambil pekerjaan sampingan atau tambahan dikarenakan status sosial perempuan yang jauh dibawah laki-laki, namun sekarang perempuan mampu berpartisipasi aktif, salah satunya dengan tidak menjadi apatis dan bergerak berdampingan dengan laki-laki dalam menciptakan ruang publik untuk menyampaikan opini bersama.

Walaupun perempuan mampu berada di ruang sosial yang sama dengan laki-laki namun masih terdapat diskriminasi terhadap perempuan. Terlihat dari posisi perempuan seringkali ditempatkan di bawah laki-laki baik di dalam organisasi ataupun dalam pembagian pekerjaan. Dapat dikatakan perempuan hanya diberikan tempat sebagai pengurus bukan posisi untuk memimpin. Padahal seperti kita tahu bahwa kapabilitas perempuan dalam menangani sesuatu hampir sama jika dibandingkan dengan laki-laki.

Masyarakat seringkali mengandalkan pemerintah negaranya dalam menyelesaikan permasalahan tersebut. Namun sungguh disayangkan pemerintah di berbagai negara kurang peka dan kurang sigap menangani masalah mengenai kesetaraan gender ini. Timbul ketidakpuasan dari masyarakat, khususnya perempuan, akibat sikap dan tanggapan dari pemerintah negara mereka sendiri tersebut. Sadar bahwa suara mereka tidak ditanggapi dengan baik maka menyebabkan munculnya banyak gerakan ataupun organisasi yang dianggap sebagai salah satu cara untuk memecahkan permasalahan ini. Organisasi yang dibentuk oleh masyarakat ini umumnya bersifat internasional karena anggotanya yang berasal dari berbagai negara, begitu pula dengan peraturannya yang dibuat dari ide dan kesepakatan bersama dari para anggota.

Salah satu organisasi yang dibentuk oleh negara-negara di dunia adalah Perserikatan Bangsa-Bangsa (United Nations). PBB merupakan sebuah organisasi internasional yang berdiri sejak tahun 1945 dan memiliki anggota 193 negara. ${ }^{1}$ Di abad ke-21 ini, PBB sangat fokus pada berbagai macam permasalahan dunia. Salah satu fokusnya adalah kesetaraan gender dimana PBB menyadari bahwa setiap tahun jutaan perempuan mengalami diskriminasi baik berupa kekerasan fisik maupun psikis. $^{2}$

\footnotetext{
${ }^{1}$ United Nations, About UN: Overview, http://www.un.org/en/sections/aboutun/overview/index.html diakses 29 Maret 2016 pada pukul 19.08 WIB

${ }^{2}$ United Nations, Ending Violence Against Women and Girls: Overview, http://www.un.org/en/globalissues/briefingpapers/e ndviol/index.shtml diakses 29 Maret 2016 pada pukul 19.26 WIB
} 
3 Angelia Maria Valentina dan Elisabeth A. Satya Dewi Implementasi CEDAW tentang Penghapusan Diskriminasi Perempuan: Studi Kasus Pemilu di Indonesia Tahun 2009 dan 2014

Fenomena tersebut mengakibatkan PBB menghasilkan sebuah konvensi yang dijadikan sebagai instrumen internasional pada tahun 1979 mengenai penghapusan segala bentuk diskriminasi terhadap perempuan, yang dinamakan sebagai Konvensi Internasional CEDAW (Convention on Elimination of All Form of Discrimination Against Women). ${ }^{3}$ Konvensi ini mulai berlaku sejak tanggal 3 Desember 1981 dan sebanyak sembilan puluh persen negara-negara anggota PBB merupakan negara peserta konvensi. ${ }^{4}$

Konvensi tersebut menetapkan persamaan hak asasi perempuan yang meliputi status perkawinan, dan peran perempuan di semua bidang yang meliputi politik, ekonomi, sosial dan budaya. ${ }^{5}$ Sebagai negara anggota PBB, Indonesia dengan jumlah penduduk kurang lebih 255 juta jiwa di tahun 2016 ini, menjadi salah satu negara peserta konvensi CEDAW. ${ }^{6}$

\section{Konvensi Internasional CEDAW}

Indonesia adalah salah satu negara yang meratifikasi Konvensi Internasional CEDAW

\footnotetext{
3 UN Women, Konvensi Penghapusan Segala Bentuk Diskriminasi terhadap Perempuan (CEDAW), hlm. 1, http://www.unwomeneseasia.org/projects/Cedaw/docs/KonvensiCEDAW textBahasa.pdf diakses 29 Maret 2016 pada pukul 19.29 WIB

${ }^{4}$ Ibid.,

5 Ibid.,

6 Indonesia-Investments, Penduduk Indonesia, http://www.indonesia-

investments.com/id/budaya/penduduk/item67

diakses 13 September 2016 pada pukul 17.27 WIB
}

menjadi UU RI No. 7 Tahun $1984 .^{7}$ Indonesia meratifikasi Konvensi CEDAW pada tanggal 24 Juli 1984 dan sepakat untuk mencegah segala tindakan diskriminasi dan menjalankan kebijakan-kebijakan yang terkait dengan penghapusan diskriminasi terhadap perempuan. $^{8}$

$$
\text { Indonesia memegang janji untuk }
$$
berkomitmen dengan instrumen internasional ini, terlihat dari keikutsertaan Indonesia dalam menandatangani Protokol Opsional untuk Konvensi CEDAW pada Februari 2000. ${ }^{9}$ Namun sayang, hingga sekarang Indonesia belum meratifikasi Protokol Opsional. Protokol Opsional merupakan wewenang yang diberikan kepada Komite CEDAW untuk ikut serta dalam upaya penyelesaian masalah yang ada di dalam negara jika terbukti adanya pelanggaran hak oleh pemerintah negara yang bersangkutan.

Ratifikasi Konvensi CEDAW di Indonesia terlihat dengan adanya Undang-Undang Nomor 7 Tahun 1984 tentang Pengesahan

7 Undang-Undang Republik Indonesia Nomor 7 Tahun 1984 Tentang Pengesahan Konvensi mengenai Penghapusan Segala Bentuk Diskriminasi Terhadap Perempuan (Convention on Elimination of All Form of Discrimination Against Women),

http://www.kemenpppa.go.id/jdih/peraturan/UU_19 84_7.pdf diakses 29 Maret 2016 pada pukul 20.06 WIB

8 Ibid.

9 UN Women Asia and the Pasific, CEDAW \& Human Rights : Indonesia, http://asiapacific.unwomen.org/en/focusareas/cedaw-human-rights/indonesia diakses 16 Oktober 2016 pada pukul 19.29 WIB 
4 Angelia Maria Valentina dan Elisabeth A. Satya Dewi Implementasi CEDAW tentang Penghapusan Diskriminasi Perempuan: Studi Kasus Pemilu di Indonesia Tahun 2009 dan 2014

Konvensi mengenai Penghapusan Segala

Bentuk Diskriminasi Terhadap Perempuan (CEDAW). ${ }^{10}$ Di dalam UU Nomor 7 Tahun 1984 dijelaskan bahwa :

Ketentuan dalam Konvensi ini tidak akan mempengaruhi asas dan ketentuan dalam peraturan perundangundangan nasional yang mengandung asas persamaan hak antara pria dan wanita sebagai perwujudan tata hukum Indonesia yang sudah kita anggap baik atau lebih baik bagi, dan sesuai, serasi serta selaras dengan aspirasi bangsa Indonesia. Sedang dalam pelaksanaannya, ketentuan dalam Konvensi ini wajib disesuaikan dengan tata kehidupan masyarakat yang meliputi nilai-nilai budaya, adat istiadat serta norma-norma keagamaan yang masih berlaku dan diikuti secara luas oleh masyarakat Indonesia. ${ }^{11}$

Penjelasan di dalam peraturan perundang-undangan tersebut dapat dikaitkan dengan definisi dari diskriminasi, hal yang ingin diperangi oleh negara Indonesia. Kebutuhan masyarakat Indonesia tidak boleh terabaikan dan harus terpenuhi dengan baik. Adanya pengratifikasian Konvensi ini

${ }^{10}$ Asosiasi Perempuan Indonesia untuk Keadilan, Pelaksanaan Konvensi Penghapusan Segala Bentuk Diskriminasi Terhadap Perempuan, APIK, hlm. 19

11 Asosiasi Perempuan Indonesia untuk Keadilan, Op. Cit., hlm. 21 bertujuan untuk menyamaratakan pemenuhan hak dari seluruh elemen masyarakat.

$$
\text { Implementasi yang dilakukan oleh }
$$
Indonesia secara langsung diawasi oleh PBB melalui Kementerian Pemberdayaan Perempuan dan Perlindungan Anak Indonesia dan CEDAW Working Initiative (CWGI) selaku organisasi non-pemerintah (NGO) di Indonesia terkait implementasi Konvensi CEDAW. CWGI sendiri adalah gabungan dari sepuluh organisasi non-pemerintah yang secara rutin menyusun laporan hasil pemantauan mengenai pelaksanaan Konvensi CEDAW. ${ }^{12}$

\section{Partisipasi Politik Perempuan di Indonesia dilihat dari Pemilu 2009 dan 2014}

Fenomena kehidupan politik di berbagai negara salah satunya di Indonesia sangat beragam dan menarik. Dunia politik Indonesia dipenuhi oleh aktivitas partai politik yang mendukung pencalonan seorang presiden beserta wakilnya, anggota legislatif, gubernur, walikota hingga kepala daerah melalui Pemilihan Umum (Pemilu) yang diselenggarakan 5 tahun sekali.

Pemilu pertama kali diselenggarakan di Indonesia pada saat jaman Orde Lama tahun

12 CEDAW Working Initiative (CWGI), 2007, Laporan Independen NGO : Implementasi Konvensi Penghapusan Segala Bentuk Diskriminasi Terhadap Perempuan (CEDAW) di Indonesia, hlm. 5 
5 Angelia Maria Valentina dan Elisabeth A. Satya Dewi Implementasi CEDAW tentang Penghapusan Diskriminasi Perempuan: Studi Kasus Pemilu di Indonesia Tahun 2009 dan 2014

1955..$^{13}$ Dilanjutkan pada tahun 1977, 1982, 1987, 1992 dan 1997 yang berlangsung dibawah pemerintahan Presiden Soeharto. Memasuki pergantian masa jabatan dari Soeharto ke masa Reformasi, pemilu diadakan di tahun 1999. Baru kemudian dilanjutkan di tahun 2004.

Jumlah partisipasi politik perempuan dapat dikatakan mengalami peningkatan dan penurunan secara tidak pasti setiap periodenya. Dari pemilu tahun 1955 sampai 2004, angka tertinggi jumlah keterwakilan perempuan di parlemen terdapat di pemilu 1992 dimana mencapai angka sebesar $12,60 \% .^{14}$ Jumlah tersebut dapat dikatakan sangat jauh jika dibandingkan dengan jumlah laki-laki di parlemen.

Indonesia sendiri dapat dikatakan menganut sistem budaya patriarki dimana sistem yang ada cenderung memihak pada laki-laki. Pemahaman mengenai sistem tersebut membawa dampak akan lahirnya kelompok dominan yang dilandaskan oleh

13 Rahmad Ardiansyah, Pemilihan Umum 1955, http://www.idsejarah.net/2014/11/pemilihanumum-1955.html diakses 12 November 2016 pada pukul 03.33 WIB

14 Komisi Pemilihan Umum, Buku Data dan Infografik : Pemilu Anggota DPR RI \& DPD RI 2014, hlm. 145, http://www.kpu.go.id/koleksigambar/Buku_Pemilu _2014_Dalam_Angka_ACC_Upload.pdf diakses 12 November 2016 pada pukul 18.28 WIB budaya, agama dan kepentingan politik. ${ }^{15}$ Gejala seperti inilah yang dapat menyebabkan adanya ketidakadilan dan ketimpangan gender yang tercipta dari marginalisasi, stereotipe dan subordinasi atas perempuan. ${ }^{16}$

Pemilu di Indonesia telah dijalankan sebanyak kurang lebih 11 kali salah satunya pada tahun 2009. Pada pemilu ini sebanyak 38 partai berpartisipasi dan tiga partai terbesar mendapatkan suara terbanyak yaitu Partai Demokrat, Partai Golongan Karya (Golkar) dan diikuti oleh Partai Demokrasi Indonesia Perjuangan (PDIP) ${ }^{17}$

Lalu pemungutan suara dilanjutkan di tahun 2014 yang diselenggarakan pada 9 April 2014 dimana sesuai dengan Undang-Undang Nomor 5 Tahun 2011 tentang Penyelenggara Pemilihan Umum dan Undang-Undang Nomor 8 Tahun 2012 tentang Pemilu Anggota DPR, DPD dan DPRD bahwa penyelengaraan pemilu harus dilaksanakan tepat waktu. ${ }^{18}$ Suara

15 Umaimah Wahid, 2014, Risalah Politik Perempuan : Media Massa dan Gerakan Counter, Tangerang : Empat Pena Publishing, hlm. 13

${ }^{16}$ Ibid.,

${ }^{17}$ KPU Indonesia, Money Politik dan Implikasinya Terhadap Partisipasi Masyarakat Kabupaten Cirebon pada Pemilu Legislatif 2014, hlm. 2, http://www.kpu.go.id/koleksigambar/Money_Politi k_dan_Implikasinya_thd_Partisipasi_Masyarakat_ Cirebon.pdf diakses 12 November 2016 pada pukul 20.45 WIB

${ }^{18}$ Komisi Pemilihan Umum, Laporan Pencalonan DPR, DPD dan DPRD 2014, hlm. 4, http://www.kpu.go.id/koleksigambar/03._laporan_p encalonan_pileg_.pdf diakses 14 November 2016 pada pukul 11.36 WIB 
6 Angelia Maria Valentina dan Elisabeth A. Satya Dewi Implementasi CEDAW tentang Penghapusan Diskriminasi Perempuan: Studi Kasus Pemilu di Indonesia Tahun 2009 dan 2014

terbanyak pada saat pemilu 2014 berlangsung didapatkan oleh tiga partai besar yaitu Partai Nasdem, Partai Golkar dan Partai Gerindra (lihat tabel 2).

Tabel 1. Daftar Calon Legislatif Tetap 2009 dan 2014

\begin{tabular}{|c|c|c|c|c|}
\hline \multirow{2}{*}{ Partai } & \multicolumn{2}{|c|}{2009} & \multicolumn{2}{c|}{2014} \\
\cline { 2 - 5 } & Laki-laki & Perempuan & Laki-laki & Perempuan \\
\hline Nasdem & 0 & 0 & 343 & 216 \\
\hline PKB & 264 & 134 & 350 & 208 \\
\hline PKS & 367 & 212 & 301 & 191 \\
\hline PDIP & 405 & 222 & 366 & 194 \\
\hline Golkar & 447 & 194 & 360 & 200 \\
\hline Gerindra & 280 & 116 & 364 & 193 \\
\hline Demokrat & 450 & 221 & 356 & 204 \\
\hline PAN & 419 & 177 & 358 & 202 \\
\hline PPP & 345 & 127 & 335 & 213 \\
\hline Hanura & 419 & 186 & 359 & 199 \\
\hline Total & $\mathbf{3 . 3 9 6}$ & $\mathbf{1 . 5 8 9}$ & $\mathbf{3 . 4 9 2}$ & 2.020 \\
\hline
\end{tabular}

Tabel 2. Daftar Anggota DPR RI 2009-2014 dan 2014-2019

\begin{tabular}{|c|c|c|c|c|}
\hline \multirow{2}{*}{ Partai } & \multicolumn{2}{|c|}{2009} & \multicolumn{2}{c|}{ 2014 } \\
\cline { 2 - 5 } & Laki-laki & Perempuan & Laki-laki & Perempuan \\
\hline Nasdem & 0 & 0 & 88 & 21 \\
\hline PKB & 22 & 6 & 31 & 4 \\
\hline PKS & 54 & 3 & 37 & 10 \\
\hline PDIP & 79 & 15 & 39 & 1 \\
\hline Golkar & 92 & 14 & 75 & 16 \\
\hline Gerindra & 23 & 3 & 62 & 13 \\
\hline Demokrat & 119 & 29 & 48 & 9 \\
\hline PAN & 41 & 5 & 29 & 10 \\
\hline PPP & 33 & 5 & 14 & 2 \\
\hline Hanura & 13 & 4 & $\mathbf{4 6 3}$ & $\mathbf{9 7}$ \\
\hline Total & $\mathbf{4 7 6}$ & $\mathbf{8 4}$ & & 13 \\
\hline
\end{tabular}


7 Angelia Maria Valentina dan Elisabeth A. Satya Dewi Implementasi CEDAW tentang Penghapusan Diskriminasi Perempuan: Studi Kasus Pemilu di Indonesia Tahun 2009 dan 2014

Di dalam tulisan ini hanya menghitung suara dari 10 partai nasional yang mendominasi pemilu tahun 2009 dan partai yang juga ikut serta dalam pemilu tahun 2014 sehingga mempermudah dalam melihat perbandingannya. Adapun sepuluh partai tersebut yaitu Partai Nasional Demokrat (Nasdem), Partai Kebangkitan Bangsa (PKB), Partai Keadilan Sejahtera (PKS), Partai Demokrasi Indonesia Perjuangan (PDIP), Partai Golongan Karya (Golkar), Partai Gerakan Indonesia Raya (Gerindra), Partai Demokrat, Partai Amanat Nasional (PAN), Partai Persatuan Pembangunan (PPP) dan Partai Hati Nurani Rakyat (Hanura).

\section{GEM (Gender Empowerment Measure)}

Dalam melihat keberhasilan pelaksanaan Konvensi CEDAW yang telah diratifikasi oleh Pemerintah Indonesia ke dalam UndangUndang Nomor 7 Tahun 1984, dibutuhkan sebuah indikator sesuai standar internasional. Banyak indikator yang dapat digunakan untuk mengukur keberhasilan dari implementasi sebuah konvensi ke dalam kehidupan masyarakat. Termasuk diantaranya indikator yang dapat melihat keberhasilan dari penerapan kesetaraan gender yang biasa dikenal dengan indikator gender.

Indikator gender diperlukan untuk melihat dan memperbaiki permasalahan gender yang diharapkan dapat mengubah pandangan masyarakat. Indikator sendiri adalah sebuah kriteria atau tindakan yang digunakan untuk melihat perubahan yang dapat dinilai. ${ }^{19}$ Indikator tersebut dapat berupa fakta, angka ataupun persepsi yang dapat menandakan perubahan atau kemajuan situasi dalam mencapai tujuan tertentu. ${ }^{20}$

Salah satu indikator gender yang dapat digunakan di Indonesia dalam melihat implementasi dari diratifikasinya salah satu konvensi mengenai penghapusan diskriminasi terhadap perempuan terkait kesetaraan gender adalah Indikator Pemberdayaan Perempuan (Gender Empowerment Measure). GEM adalah salah satu indikator yang digunakan untuk mengukur keterwakilan perempuan di dalam bidang ekonomi dan politik. ${ }^{21}$ Indikator ini juga melihat adanya kesenjangan gender dalam representasi politik, posisi profesional dan manajemen dalam perekonomian, serta kesenjangan gender dalam pendapatan. ${ }^{22}$ GEM merupakan gagasan yang diberikan oleh

\footnotetext{
${ }^{19}$ Bride Development, Gender Indicators : What, Why and How?, hlm. 1, http://www.oecd.org/dac/genderdevelopment/43041409.pdf diakses 14 November 2016 pada pukul 11.44 WIB

${ }^{20}$ Ibid.,

${ }^{21}$ Badan Pusat Statistik, 2014, Indeks Pembangunan Gender 2014, hlm. 5, https://www.bps.go.id/index.php/publikasi/1137 diakses 14 November 2016 pada pukul 10.43 WIB ${ }^{22}$ Ibid.,
} 
8 Angelia Maria Valentina dan Elisabeth A. Satya Dewi Implementasi CEDAW tentang Penghapusan Diskriminasi Perempuan: Studi Kasus Pemilu di Indonesia Tahun 2009 dan 2014

United Nations Development Programme (UNDP) pada tahun $1995 .^{23}$

Di tahun 1995 ketika konsep GEM diperkenalkan oleh UNDP, GEM dikaitkan dengan inisiatif untuk mempersempit kesenjangan antara laki-laki dan perempuan yang mengacu pada kesempatan dan partisipasi laki-laki dan perempuan dalam pembangunan. Ada empat indikator di dalam GEM itu sendiri antara lain :

1. Proporsi posisi profesional dan pekerja teknis perempuan (The proportion of women professionals and technical workers);

2. Proporsi legislator perempuan, pejabat senior dan manajer (The proportion of women legislators, senior officials and managers);

3. Proporsi jumlah kursi yang dipegang oleh perempuan di parlemen (The proportion of seats held by women in parliament);

4. Rasio pendapatan perempuan dan laki-laki (The ratio of women to men earned income). ${ }^{24}$

${ }^{23}$ Stephen Klasen and Dana Schu ler, Reforming The Gender-Related Development Index and The Gender Empowerment Measure : Implementing Some Spesific Proposals, Feminist Economics 17(1), Januari 2011, hlm. 1-30

24 Maimunah Ismail, Roziah Mohd Rasdi dan Akhmal Nadirah, Gender Empowerment Measures
Di dalam tulisan ini, digunakan indikator mengenai proporsi perempuan di kursi parlemen. Indikator ini digunakan untuk mengukur keberhasilan perempuan dalam menduduki kursi parlemen di pemerintahan. Perhitungan yang mendasari keterwakilan perempuan di parlemen juga bergantung pada populasi laki-laki dan perempuan di suatu negara. Jumlah populasi perempuan harus sebanding dengan jumlah keterwakilan perempuan di parlemen baru dapat dikatakan bahwa sebuah negara berhasil menerapkan kesetaraan gender. ${ }^{25}$

Seperti contoh jika jumlah perempuan di sebuah negara berjumlah 55 persen dari populasi penduduk, seharusnya kedudukan perempuan di parlemen juga sebanyak 55 persen. Di Indonesia jumlah populasi perempuan 49 persen dari total keseluruhan jumlah penduduk, sehingga seharusnya angka partisipasi perempuan harus 49 persen pula dikarenakan rasio $1: 1 .^{26}$ Perhitungan yang digunakan sebagai acuan untuk mengukur keberhasilan kedudukan perempuan di

in Developed and Developing Countries : Evidence and Implication for Human Resource Development, hlm 4-8, http://www.ufhrd.co.uk/wordpress/wpcontent/uploads/2010/08/7_2.pdf diakses 15 November 2016 pada pukul 02.53 WIB

${ }^{25}$ Stephen Klasen and Dana Schu ler, Op.Cit.,

26 Jumlah Penduduk Indonesia Sudah 254,9 Juta, Laki-laki Lebih Banyak Dari Perempuan, 2015, http://www.hidayatullah.com/berita/nasional/read/2 015/11/20/83632/jumlah-pendududariperempuan.html diakses 13 November 2016 pada pukul 03.01 WIB 
9 Angelia Maria Valentina dan Elisabeth A. Satya Dewi Implementasi CEDAW tentang Penghapusan Diskriminasi Perempuan: Studi Kasus Pemilu di Indonesia Tahun 2009 dan 2014

parlemen diambil dari sebuah tulisan yang ditulis oleh Stephan Klasen dan Dana Schuler, feminis yang berasal dari Jerman. ${ }^{27}$

\section{Implementasi Konvensi CEDAW di Indonesia}

Adanya peraturan pemerintah mengenai hak asasi manusia yang sekaligus mengatur mengenai hak perempuan salah satunya hak dalam berpolitik, membuktikan bahwa kesetaraan hak asasi manusia di Indonesia telah diperjuangkan dengan baik. Namun sayangnya di kehidupan nyata masih banyak ketidakadilan dan tindakan kekerasan yang diterima oleh perempuan. Padahal ketika seseorang melanggar hak seorang perempuan maka perbuatan tersebut patut ditindaklanjuti karena bertentangan dengan hukum yang berlaku di Indonesia.

Melalui Konvensi Internasional CEDAW yang diratifikasi oleh Indonesia di tahun 1984, emansipasi perempuan yang mulai diserukan oleh perempuan-perempuan Indonesia perlahan tidak lagi dipandang sebelah mata oleh masyarakat khususnya pemerintah. Dengan jaman yang telah berubah dan ruang publik yang lebih terbuka, keikutsertaan

27 Feminist Economics, 2011, Reforming The Gender-Related Development Index and The Gender Empowerment Measure : Implementing Some Spesific Proposals, http://www.ccee.edu.uy/ensenian/catgenyeco/Mater iales/2011-08-10\%20M6\%20-

\%20KlasenShuler(2011).pdf diakses 13 November 2016 pada pukul 03.19 WIB perempuan menjadi hal yang tidak tabu lagi. Namun perlu diingat, fakta di lapangan bahwa budaya patriarki masih berkembang luas di masyarakat.

Jika dilihat dari data pemilu tahun 2009 dan 2014 (lihat tabel 1 dan 2), tingkat efektivitas dari implementasi Konvensi CEDAW sendiri di Indonesia masih belum tercapai. Di dalam Konvensi CEDAW, melalui Undang-Undang Nomor 7 Tahun 1984, mengatakan bahwa penghapusan diskriminasi terhadap perempuan dapat dilakukan melalui tindakan afirmasi. ${ }^{28}$ Padahal hak berpolitik adalah hak semua masyarakat.

Hal tersebut diatur dalam Undang-Undang No. 39 Tahun 1999 yang mengatur mengenai Hak Asasi Manusia (HAM). UU ini memiliki ketentuan bahwa setiap manusia memiliki hak yang merekat pada dirinya sejak lahir. Pasal ini juga menjelaskan apa yang dimaksud dengan diskriminasi. Dengan kata lain pemerintah Indonesia telah mengatur persamaan hak antara laki-laki dan perempuan sebagaimana mestinya.

Affirmative action adalah salah satu upaya yang telah diperjuangkan untuk memenuhi

\footnotetext{
${ }^{28}$ Achie Sudiarti, Pengujian UU Republik Indonesia dan Instrumen HAM Internasional Konvensi Penghapusan Segala Bentuk Diskriminasi Terhadap Wanita Disahkan Dengan UU Republik Indonesia No. 7 Tahun 1984, hlm. 4, https://www.k4health.org/sites/default/files/CEDA W_document.pdf diakses 3 Desember 2016 pada pukul 12.12 WIB
} 
10 Angelia Maria Valentina dan Elisabeth A. Satya Dewi Implementasi CEDAW tentang Penghapusan Diskriminasi Perempuan: Studi Kasus Pemilu di Indonesia Tahun 2009 dan 2014

jumlah yang sama antara laki-laki dan perempuan di bidang politik. Tindakan afirmatif tersebut adalah tindakan sementara yang diambil untuk mempercepat pencapaian kesempatan guna mencapai keadilan dan persamaan. ${ }^{29}$ Pemerintah Indonesia telah mengatur di dalam UU Nomor 12 Tahun 2003 tentang Pemilihan Umum DPR, DPD dan DPRD, yang mencantumkan himbauan untuk memenuhi keterwakilan perempuan sejumlah $30 \%$ dalam pencalonan anggota legislatif di masing-masing partai politik.

Di dalam UU Nomor 12 Tahun 2003 pasal 65 ayat 1 menyatakan bahwa :

Setiap partai politik peserta Pemilu dapat mengajukan calon anggota DPR, DPRD Provinsi dan DPRD Kabupaten/Kota, untuk setiap daerah pemilihan dengan memperhatikan keterwakilan perempuan sekurangkurangnya 30 persen. $^{30}$

Upaya yang dilakukan Pemerintah Indonesia merupakan gerakan untuk menciptakan kehidupan politik yang demokratis bagi perempuan Indonesia ternyata

\footnotetext{
${ }^{29}$ R. Valentina, 2003, Apa Sesungguhnya Substansi Kuota $30 \%$, http://www.institutperempuan.or.id/?p=17 diakses 3 Desember 2016 pada pukul 08.45 WIB

${ }^{30}$ Bustanul Arif, Nadia dan Ical, Partisipasi Politik Perempuan dalam proses pembuatan kebijakan publik di daerah Jawa Timur, Yayasan Cakrawala Timur dan PGRI dan Uni Eropa, hlm 60
}

telah sejak lama dirancang oleh negara-negara di dunia. Melalui Kongres Asosiasi Uni Parlemen (APU) tahun 1995, mulai disepakati kuota $30 \%$ di parlemen bagi perempuan. ${ }^{31}$ Hal tersebut dipertegas dalam Kongres Perempuan Sedunia tahun 1996 di Beijing, Tiongkok. ${ }^{32}$

Keputusan dan kesepakatan yang terbentuk melalui kedua kongres tersebut yang kemudian dijadikan landasan mengenai kuota $30 \%$ untuk meningkatkan partisipasi perempuan. Jumlah perempuan yang terus menjadi minoritas mendukung adanya Beijing Platform for Action, yang menekankan bahwa partisipasi perempuan yang setara bukan hanya mengenai tuntutan keadilan di mata hukum namun kepentingan perempuan yang harus diperhitungkan juga. ${ }^{33}$

Beijing Platform ini memberikan kontribusi dalam peningkatan kesadaran dalam menyeimbangkan kedudukan perempuan dan laki-laki dengan adanya kesepakatan untuk menerapkan affirmative action. Terbukti bahwa Beijing Platform ini, bersifat lintas batas negara karena diikuti oleh negara anggota PBB yang salah satunya adalah Indonesia.

31 Umaimah Wahid, 2014, Risalah Politik Perempuan : Media Massa dan Gerakan Counter Hegemony, Tangerang : Empat Pena Publishing, hlm. 126

${ }^{32}$ Ibid., hlm. 125

${ }^{33}$ UN Women, Women in Power and DecisionMaking,

http://www.un.org/womenwatch/daw/followup/sess ion/presskit/fs7.htm diakses 20 Desember 2016 pada pukul 10.55 WIB 
11 Angelia Maria Valentina dan Elisabeth A. Satya Dewi Implementasi CEDAW tentang Penghapusan Diskriminasi Perempuan: Studi Kasus Pemilu di Indonesia Tahun 2009 dan 2014

Affirmative action sebenarnya merupakan rekomendasi Dewan Sosial dan Ekonomi PBB (Ecosoc) agar negara-negara anggota PBB dapat memenuhi target $30 \%$ ini. $^{34}$ Tindakan afirmatif ini juga telah diatur di dalam Rekomendasi Umum Komite PBB untuk Penghapusan Diskriminasi terhadap Perempuan Nomor 5 Tahun 1988, Nomor 23 Tahun 1998 dan Komentar Umum Nomor 4 dan 18 dari Komisi Hak Asasi Manusia, yang wajib dilaksanakan bagi seluruh anggota PBB. $^{35}$

Kebijakan tersebut kemudian diterapkan oleh Indonesia pertama kali pada saat Pemilu tahun 1999. ${ }^{36}$ Pemilu di tahun 1999 dinilai demokratis dan terbuka namun sayang pelaksanaan kebijakan afirmasi tidak berjalan dengan baik sehingga tidak ada perubahan dan peningkatan jumlah keterwakilan perempuan seperti yang diharapkan.

Dilihat dari fakta di lapangan yang membuktikan bahwa jumlah perempuan belum dapat mencapai angka $30 \%$ tersebut, pemerintah tidak berhenti pada kebijakan afirmatif saja. Pemerintah menerapkan adanya zipper system, dimana adanya pengaturan mengenai bakal calon dari masing-masing

\footnotetext{
34 Umaimah Wahid, 2014, Risalah Politik Perempuan : Media Massa dan Gerakan Counter Hegemony, Tangerang : Empat Pena Publishing, hlm. 131

${ }^{35}$ Ibid., hlm. 126

${ }^{36}$ Ibid.,
}

partai politik yang mencalonkan diri menjadi anggota parlemen sekurang-kurangnya terdapat satu orang perempuan. ${ }^{37}$ Kebijakan ini diatur berdasarkan Undang-Undang No. 10 Tahun 2008 Pasal 55 ayat 2, yang menyatakan bahwa :

$$
\begin{aligned}
& \text { Di dalam daftar bakal calon } \\
& \text { sebagaimana dimaksud pada ayat (1), } \\
& \text { setiap } 3 \text { (tiga) orang bakal calon } \\
& \text { terdapat sekurang-kurangnya } 1 \text { (satu) } \\
& \text { orang perempuan bakal calon }{ }^{38}
\end{aligned}
$$

Zipper system juga mengatur mengenai urutan bakal calon perempuan yang harus ditempatkan pada nomor urut pertama. Hal tersebut guna mempermudah masyarakat dalam memilih. Hal tersebut tidak untuk mengistimewakan perempuan dan pelaksanaannya juga tidak selamanya karena affirmative action dilakukan untuk masa tertentu dan harus diberhentikan apabila keadilan dan kesetaraan gender telah tercapai di dalam kehidupan politik. ${ }^{39}$

\footnotetext{
37 Ignatius Mulyono, Strategi Meningkatkan Keterwakilan Perempuan, hlm. 3, http://www.dpr.go.id/dokakd/dokumen/makalah_S TRATEGI_MENINGKATKAN_KETERWAKILA N_PEREMPUAN_Oleh-_Ignatius_Mulyono.pdf diakses 4 Desember 2016 pada pukul 08.49 WIB

${ }^{38}$ Ibid.,

${ }^{39}$ R. Valentina, 2003, Apa Sesungguhnya Substansi Kuota 30\%, http://www.institutperempuan.or.id/?p=17 diakses 3 Desember 2016 pada pukul 09.00 WIB
} 
12 Angelia Maria Valentina dan Elisabeth A. Satya Dewi Implementasi CEDAW tentang Penghapusan Diskriminasi Perempuan: Studi Kasus Pemilu di Indonesia Tahun 2009 dan 2014

Jika dilihat dari diratifikasinya Konvensi CEDAW di Indonesia dan kebijakan yang sudah pemerintah Indonesia lakukan untuk mengurangi adanya diskriminasi terhadap perempuan, angka partisipasi perempuan setiap pemilu diadakan seharusnya dapat meningkat secara perlahan untuk menyentuh angka yang sama dengan jumlah laki-laki. Seperti diketahui jumlah laki-laki yang ada di parlemen lebih dari separuh jumlah keseluruhan anggota DPR. Hal tersebut terlihat dari pemilu di tahun 2009 dan 2014.

\section{Kesimpulan}

Jumlah perempuan yang terjun ke dunia politik terlihat mengalami peningkatan walaupun tidak terjadi setiap pemilu dilangsungkan. Peningkatan jumlah perempuan yang aktif dalam dunia politik serta terpilih menjadi anggota dewan legislatif setiap pemilu memiliki dampak yang baik. Dampak baik yang dimaksud adalah jumlah perempuan yang peka terhadap masalah politik yang menyangkut kehidupan orang banyak termasuk perempuan, semakin bertambah dan berdampak positif tentu bagi kebutuhan perempuan.

Namun di sisi lain, timbulnya kekhawatiran mengenai jumlah perempuan yang tidak dapat menyimbangi jumlah lakilaki di parlemen harus dapat ditanggapi dengan serius. Peningkatan keterwakilan perempuan terlihat apabila dibandingkan dengan tahun-tahun sebelumnya, akan tetapi jika dibandingkan dengan jumlah laki-laki, jumlah perempuan masih tertinggal jauh. Untuk mencapai angka 30\% seperti kebijakan afirmatif sementara yang ditetapkan oleh pemerintah Indonesia saja, perempuan masih menemukan kesulitan apalagi menyeimbangkan jumlah suara di parlemen seperti yang dimiliki oleh kaum laki-laki.

Tugas perempuan hanya dikaitkan dengan urusan domestik sedangkan laki-laki identik dengan urusan publik. Padahal dengan adanya perempuan, kepentingan dan kebutuhan terkait perempuan akan lebih terakomodir mengingat apabila kehidupan politik hanya dipenuhi oleh kaum laki-laki, sudut pandang mengenai pembuatan kebijakan dan pengambilan keputusan dapat menguntungkan satu pihak yaitu laki-laki saja.

Untuk dapat menyeimbangkan representasi politik antara laki-laki dan perempuan dibutuhkan sejumlah peningkatan dalam kehidupan politik perempuan. Pertama, peningkatan wawasan politik perempuan. Tidak banyak perempuan yang mengerti bagaimana menjalankan tugas negara yang diberikan kepada mereka ketika mereka menjadi wakil rakyat. Hal tersebut dikarenakan pendidikan politik perempuan masih rendah sehingga tidak banyak dari mereka yang hanya menjadi penonton dan menolak untuk terjun langsung. Kedua, 
13 Angelia Maria Valentina dan Elisabeth A. Satya Dewi Implementasi CEDAW tentang Penghapusan Diskriminasi Perempuan: Studi Kasus Pemilu di Indonesia Tahun 2009 dan 2014

peningkatan kepedulian perempuan berkaitan dengan penyampaian aspirasi dan kebutuhan perempuan. Jumlah perempuan yang ada di parlemen mempengaruhi sebuah keputusan yang dibuat. Laki-laki tidak dapat sepenuhnya mengerti kebutuhan perempuan begitu sebaliknya sehingga dalam pembuatan keputusan, penyampaian keinginan masingmasing pihak harus dilakukan.

Terakhir, peningkatan peluang kesempatan bagi perempuan sehingga starting point lakilaki dan perempuan tidak berbeda jauh. Perempuan harus diberikan kesempatan yang lebih besar agar dapat menyeimbangkan kedudukan dengan laki-laki karena harus diakui bahwa laki-laki lebih berpengalaman.

Hak perempuan tidak dapat dipandang sebelah mata. Pendidikan politik harus diberikan kepada seluruh perempuan Indonesia sehingga penyamarataan informasi dan wawasan politik perempuan sama. Lalu budaya patriarki di masyarakat yang dirasakan adalah salah satu faktor yang menyebabkan terhambatnya tercipta kesetaraan gender di Indonesia. Budaya tersebut harus perlahanlahan dihilangkan sehingga kesempatan perempuan membantu perkembangan dan pembangunan negara dapat ditingkatkan.

Banyak perempuan yang kurang peka terhadap isu kesetaraan gender, namun masih banyak pula yang serius menangani permasalahan ini sehingga baik laki-laki dan perempuan Indonesia harus mengerti konstruksi sosial yang baik tidak dapat terbentuk tanpa partisipasi aktif kedua belah pihak. Penerapan Konvensi CEDAW masih belum efektif jika dilihat dari partisipasi politik perempuan di Indonesia.

Kesadaran dan usaha bersama masyarakat Indonesia untuk menyelesaikan permasalahan serius ini dengan cara memberikan peluang yang sama kepada perempuan dalam pembuatan kebijakan dan pengambilan keputusan. Untuk mencapai kesetaraan gender yang ideal dibutuhkan proporsi yang seimbang antara laki-laki dan perempuan serta pemikiran yang terbuka dari masyarakat yang dapat menerima perubahan. Tanpa adanya kesadaran dan dukungan masyarakat bersama, perempuan harus berjuang lebih keras untuk mendapatkan porsi didalam masyarakat.

\section{Referensi}

\section{Buku}

Arif, Bustanul. Partisipasi Politik Perempuan Dalam Proses Pembuatan Kebijakan Publik di Daerah Jawa Timur. Jawa Timur : Yayasan Cakrawala Timur.

Asosiasi Perempuan Indonesia untuk Keadilan. Pelaksanaan Konvensi Penghapusan Segala Bentuk Diskriminasi Terhadap Perempuan. APIK.

CEDAW Working Initiative (CWGI). Laporan Independen NGO: Implementasi Konvensi Penghapusan Segala Bentuk Diskriminasi Terhadap Perempuan (CEDAW) di Indonesia, 2007. 
14 Angelia Maria Valentina dan Elisabeth A. Satya Dewi Implementasi CEDAW tentang Penghapusan Diskriminasi Perempuan: Studi Kasus Pemilu di Indonesia Tahun 2009 dan 2014

Wahid, Umaimah. Risalah Politik Perempuan. Tangerang : Empat Pena Publishing, 2014.

\section{Jurnal}

Klasen, Stephen and Schuler, Dana. "Reforming The Gender-Related Development Index and The Gender Empowerment Measure: Implementing Some Spesific Proposals". Feminist Economics 17(1) hlm. 1-30, 2011.

\section{Website}

Ardiansyah, Rahmad. "Pemilihan Umum 1955". Diakses 12 November 2016 pada pukul $03.33 \quad$ WIB. http://www.idsejarah.net/2014/11/pemili han-umum-1955.html

Bride Development. "Gender Indicators : What, Why and How?". Diakses 14 November 2016 pada pukul 11.44 WIB. http://www.oecd.org/dac/genderdevelopment/43041409.pdf

Feminist Economics. "Reforming The Gender-Related Development Index and The Gender Empowerment Measure: Implementing Some Spesific Proposals". Diakses 13 November 2016 pada pukul 03.19 WIB. http://www.ccee.edu.uy/ensenian/catgen yeco/Materiales/2011-08$10 \% 20 \mathrm{M} 6 \% 20$ \%20KlasenShuler(2011).pdf

Indonesia-Investments.

"Penduduk Indonesia". Diakses 13 September 2016 pada pukul 17.27 WIB. http://www.indonesiainvestments.com/id/budaya/penduduk/it em67

Ismail, Maimunah, Roziah Mohd Rasdi dan Akhmal Nadirah. "Gender Empowerment Measures in Developed and Developing Countries: Evidence and Implication for Human Resource
Development". Diakses 15 November 2016 pada pukul 02.48 WIB. http://www.ufhrd.co.uk/wordpress/wpcontent/uploads/2010/08/7_2.pdf

Komisi Pemilihan Umum. "Buku Data dan Infografik : Pemilu Anggota DPR RI \& DPD RI 2014". Diakses 12 November 2016 pada pukul 18.28 WIB. http://www.kpu.go.id/koleksigambar/Bu ku_Pemilu_2014_Dalam_Angka_ACC_ Upload.pdf

Komisi Pemilihan Umum. "Laporan Pencalonan DPR, DPD dan DPRD 2014". Diakses 14 November 2016 pada pukul $11.36 \quad$ WIB. http://www.kpu.go.id/koleksigambar/03. _laporan_pencalonan_pileg_.pdf

KPU Indonesia. "Money Politik dan Implikasinya Terhadap Partisipasi Masyarakat Kabupaten Cirebon pada Pemilu Legislatif 2014". Diakses 12 November 2016 pada pukul 20.45 WIB. http://www.kpu.go.id/koleksigambar/M oney_Politik_dan_Implikasinya_thd_Pa rtisipasi_Masyarakat_Cirebon.pdf

"Jumlah Penduduk Indonesia Sudah 254,9 Juta, Laki-laki Lebih Banyak Dari Perempuan". Diakses 13 November 2016 pada pukul 03.01 WIB. http://www.hidayatullah.com/berita/nasi onal/read/2015/11/20/83632/jumlahpendududari-perempuan.html

Mulyono, Ignatius. "Strategi Meningkatkan Keterwakilan Perempuan". Diakses 4 Desember 2016 pada pukul 08.49 WIB. http://www.dpr.go.id/dokakd/dokumen/ makalah_STRATEGI_MENINGKATK AN_KETERWAKILAN_PEREMPUA N_Oleh-_Ignatius_Mulyono.pdf

Sudiarti, Achie. "Pengujian UU Republik Indonesia dan Instrumen HAM Internasional Konvensi Penghapusan Segala Bentuk Diskriminasi Terhadap Wanita Disahkan Dengan UU Republik Indonesia No. 7 Tahun 1984". Diakses 3 
15 Angelia Maria Valentina dan Elisabeth A. Satya Dewi Implementasi CEDAW tentang Penghapusan Diskriminasi Perempuan: Studi Kasus Pemilu di Indonesia Tahun 2009 dan 2014

Desember 2016 pada pukul 12.12 WIB. https://www.k4health.org/sites/default/fi les/CEDAW_document.pdf

United Nations. "About UN : Overview". Diakses 29 Maret 2016 pada pukul 19.08 WIB. http://www.un.org/en/sections/aboutun/overview/index.html

United Nations. "Ending Violence Against Women and Girls : Overview". Diakses 29 Maret 2016 pada pukul 19.26 WIB. http://www.un.org/en/globalissues/briefi ngpapers/endviol/index.shtml

UN Women. "Konvensi Penghapusan Segala Bentuk Diskriminasi terhadap Perempuan (CEDAW)". Diakses 29 Maret 2016 pada pukul 19.29 WIB. http://www.unwomen-

eseasia.org/projects/Cedaw/docs/Konve nsiCEDAWtextBahasa.pdf

UN Women. "Women in Power and DecisionMaking". Diakses 20 Desember 2016 pada pukul 10.55 WIB. http://www.un.org/womenwatch/daw/fo llowup/session/presskit/fs 7.htm

UN Women Asia and the Pacific. "CEDAW and Human Rights: Indonesia". Diakses 16 Oktober 2016 pada pukul 19.29 WIB.

http://asiapacific.unwomen.org/en/focus -areas/cedaw-human-rights/indonesia

"Undang-Undang Republik Indonesia Nomor 7 Tahun 1984 Tentang Pengesahan Konvensi mengenai Penghapusan Segala Bentuk Diskriminasi Terhadap Perempuan (Convention on Elimination of All Form of Discrimination Against Women)". Diakses diakses 29 Maret 2016 pada pukul 20.06 WIB. http://www.kemenpppa.go.id/jdih/peratu ran/UU_1984_7.pdf

Valentina, R. "Apa Sesungguhnya Substansi Kuota 30\%”. Diakses 3 Desember 2016 pada pukul $08.45 \quad$ WIB. http://www.institutperempuan.or.id/?p= 17 